\title{
Transient Receptor Potential Melastatin 4 (TRPM4) Contributes to High Salt Diet- Mediated Early-Stage Endothelial Injury
}

\author{
Xiao-Qing Ding ${ }^{a}$ Tao Ban ${ }^{b}$ Zeng-Yan Liu ${ }^{b}$ Jie Lou ${ }^{a}$ Liang-Liang Tanga \\ Jia-Xin Wang ${ }^{b}$ Wen-Feng Chu ${ }^{b}$ Bin-Lin Song ${ }^{a}$ Dan Zhao ${ }^{c}$ Zhi-Ren Zhanga \\ aDepartment of Cardiology and Clinical Pharmacy, Harbin Medical University Cancer Hospital, Institute \\ of Metabolic Disease, Heilongjiang Academy of Medical Science, Key Laboratories of Education \\ Ministry for Myocardial Ischemia Mechanism and Treatment, Harbin, ${ }^{b}$ Department of Pharmacology, \\ Harbin Medical University, Harbin, 'Department of Clinical Pharmacy, the 2nd Affiliated Hospital of \\ Harbin Medical University, Harbin, P. R. China
}

\section{Key Words}

Aldosterone $\cdot$ Hydrogen peroxide $・$ TRPM4 $・$ 9-phenanthrol $•$ Salt-sensitive $\cdot$ Hypertension

\begin{abstract}
Background/Aims: The present study investigated whether the transient receptor potential melastatin 4 (TRPM4) channel plays a role in high salt diet (HSD)-induced endothelial injuries. Methods: Western blotting and immunofluorescence were used to examine TRPM4 expression in the mesenteric endothelium of Dahl salt-sensitive (SS) rats fed a HSD. The MTT, TUNEL, and transwell assays were used to evaluate the cell viability, cell apoptosis, and cell migration, respectively, of human umbilical vein endothelial cells (HUVECs). Enzyme-linked immunosorbent assays were used to determine the concentrations of intercellular adhesion molecule 1 (ICAM-1), vascular cell adhesion protein 1 (VCAM-1), and E-selectin. CarboxyH2DCFDA, a membrane-permeable reactive oxygen species (ROS)-sensitive fluorescent probe, was used to detect intracellular ROS levels. Results: TRPM4 was mainly expressed near the plasma membrane of mesenteric artery endothelial cells, and its expression level increased in SS hypertensive rats fed a HSD. Its protein expression was significantly upregulated upon treatment with exogenous hydrogen peroxide $\left(\mathrm{H}_{2} \mathrm{O}_{2}\right)$ and aldosterone in cultured HUVECs. Cell viability decreased upon treatment with both agents in a concentration-dependent manner, which could be partially reversed by 9-phenanthrol, a specific TRPM4 inhibitor. Exogenous $\mathrm{H}_{2} \mathrm{O}_{2}$ induced apoptosis, enhanced cell migration, and increased the release of adhesion molecules, including ICAM-1, VCAM-1, and E-selectin, all of which were significantly attenuated upon treatment with 9-phenanthrol. Aldosterone and $\mathrm{H}_{2} \mathrm{O}_{2}$ induced the accumulation of intracellular ROS, which was significantly inhibited by 9 -phenanthrol, suggesting that oxidative stress is one of the mechanisms underlying aldosterone-induced endothelial injury. Conclusions: Given the fact that oxidative stress and high levels of circulating aldosterone are present in hypertensive patients, we suggest that the upregulation of TRPM4 in the vascular endothelium may be involved in endothelial injuries caused by these stimuli.

X.-Q. Ding and T. Ban contributed equally to this work.

Dan Zhao and Zhi-Ren Zhang

Department of Clinical Pharmacy, the 2nd Affiliated Hospital, Harbin Medical University, Harbin 150086, (P. R. China); Department of Cardiology, Harbin Medical University Cancer Hospital, Institute of Metabolic Disease, Heilongjiang Academy of Medical Science, Harbin, 150000, (P.R. China); E-Mail zhaodan7719@163.com / zhirenz@yahoo.com
\end{abstract}

KARGER 


\section{Cellular Physiology Cell Physiol Biochem 2017;41:835-848

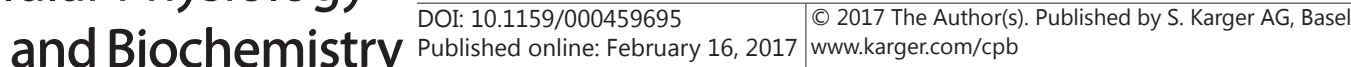 \\ Ding et al.: TRPM4 Involves in High Salt-Induced Endothelial Injury}

\section{Introduction}

The transient receptor potential (TRP) superfamily of non-selective cation channels has 28 mammalian members, and is widely expressed in many different tissues [1]. TRP channels are activated by calcium $\left(\mathrm{Ca}^{2+}\right)$, sodium $\left(\mathrm{Na}^{+}\right)$, and magnesium $\left(\mathrm{Mg}^{2+}\right)$, and conduct both monovalent and divalent cations. Similar to all TRP channels, the TRP melastatin 4 (TRPM4) channel consists of six transmembrane (TM)-spanning domains and four subunits that assemble in the plasma membrane to form functional ion channels. The selectivity filter of the ion channel pore is located between TM5 and TM6 [2]; however, TRPM4 is $\mathrm{Ca}^{2+}$-impermeable and exclusively transports monovalent cations.

TRPM4 is ubiquitously expressed in the cardiovascular, immune, and central nervous systems, and is also expressed in endothelial cells (ECs) from different vascular tissues such as mouse aortic ECs, rat brain ECs, and human pulmonary artery ECs [3]. In 2009, Gerzanich et al. [4] first reported that TRPM4 is expressed in ECs and is highly upregulated in capillaries of spinal cord injury regions. Moreover, endogenous TRPM4-like currents have been detected in human umbilical vein endothelial cells (HUVECs). There are strong indications that TRPM4 is involved in a surprising number of critical functions, including regulation of the vascular endothelium in numerous pathological processes $[5,6]$. Thus, we postulated that it may be associated with endothelial lesions.

TRPM4 can be inhibited by many compounds including intracellular spermine, flufenamic acid, quinine, quinidine, and MPB-104; however, the poor selectivity of these molecules among other ion channels has limited their application. Recently, 9-phenanthrol was identified as a selective TRPM4 blocker [7], with an $\mathrm{IC}_{50}$ of $20 \mu \mathrm{M}$ in transfected HEK293 cells and an $\mathrm{IC}_{50}$ of 1 $\mu \mathrm{M}$ in endothelial cells $[8,9]$.

Oxidative stress exists in certain organs of Dahl/salt-sensitive (SS) hypertensive rats including the kidney [10,11], brain [12], and vasculature [13-15]. Our unpublished results and other investigations have shown that a high salt diet (HSD) can induce hypertension and increase aldosterone biosynthesis in Dahl/SS rats. In contrast, Dahl/salt-resistant (SR) rats maintain the initial suppression of aldosterone biosynthesis and normal blood pressure [16].

We performed several experiments to determine whether TRPM4 is regulated during endothelium damage caused by a HSD overload, and to elucidate if TRPM4 is involved in endothelial injury caused by excessive oxidative stress or aldosterone.

\section{Materials and Methods}

\section{Reagents and Chemicals}

Unless otherwise noted, all of the reagents and chemicals were purchased from Sigma-Aldrich (St. Louis, MO, USA). Aldosterone was dissolved in ethanol to make a stock solution of $10 \mathrm{mmol} / \mathrm{L}$ (stored at $4^{\circ} \mathrm{C}$ for 2 weeks). Hydrogen peroxide $\left(\mathrm{H}_{2} \mathrm{O}_{2}\right)$ was purchased from Tianjin Guangfu Technology Development Co. Ltd (Wuqing Tianjin, China) and dissolved in saline solution for experiments. 9-phenanotrol was diluted in dimethyl sulfoxide (DMSO) to make a $1 \mathrm{mM}$ stock solution, which was further diluted to a final concentration of $1 \mu \mathrm{M}$ in the culture medium.

\section{Animals}

All of the animal procedures were approved by the Animal Supervision Committee of Harbin Medical University (Harbin, Heilongjiang, China). A total of 20 male Dahl/SS hypertensive rats were divided into two groups (10 rats in each group). The rats were housed in a controlled environment and fed with either a normal-salt diet (NSD, $0.3 \% \mathrm{NaCl}, \mathrm{w} / \mathrm{w}$ ) or $\mathrm{HSD}(8 \% \mathrm{NaCl}, \mathrm{w} / \mathrm{w})$ for 21 days. At the end of the experimental period, animals were anesthetized with diethyl ether and sacrificed. Then the second-order mesenteric arteries were rapidly isolated and carefully prepared for subsequent Western blotting and histological studies to assess the expression level of TRPM4. 


\section{Cellular Physiology Cell Physiol Biochem 2017;41:835-848 \begin{tabular}{l|l|l} 
and Biochemistry 10.1159/000459695 & $\begin{array}{l}\text { C } 2017 \text { The Author(s). Published by S. Karger AG, Basel } \\
\text { www.karger.com/cpb }\end{array}$
\end{tabular}}

Ding et al.: TRPM4 Involves in High Salt-Induced Endothelial Injury

\section{Immunofluorescent staining of TRPM4}

Prior to the experiments, mesenteric arteries from Dahl/SS rats $(n=10)$ were fixed in $4 \%$ paraformaldehyde for $2 \mathrm{~h}$ and dehydrated with $18 \%$ sucrose at $4^{\circ} \mathrm{C}$ overnight. This was followed by embedding in optimal cutting temperature (OCT) solution (TissueTek; Sakura Finetek, Torrance, CA, USA), after which the tissue was cut into sections of $5 \mu \mathrm{m}$ thickness with a freezing microtome (Leica Biosystem, Heidelberger, Germany) and stored at $-80^{\circ} \mathrm{C}$ until immunostaining. Mesenteric artery cryostat sections were fixed in acetone for $10 \mathrm{~min}$ at room temperature $\left(22-24^{\circ} \mathrm{C}\right)$, and then incubated with $1 \%$ bovine serum albumin (BSA, 05479; Fluka, Sigma) for $30 \mathrm{~min}$ to prevent non-specific binding. To ensure the accuracy of the experiment, co-staining of TRPM4 with von Willebrand factor (vWF) was performed. Specifically, the sections were incubated overnight at room temperature with optimal dilutions of rabbit polyclonal antibody to anti-TRPM4 (ACC-044, 1:50; Alomone, Jersusalem, Israel) and sheep polyclonal antibody to vWF (ab11713, 1:50; Abcam, Cambridge, MA, USA). The following day, the sections were washed and incubated with TRITC-conjugated donkey anti-sheep (ab6897, 1:1000; Abcam) and Alexa Fluor 488-conjugated donkey anti-rabbit IgG (A21206, 1:1000; Invitrogen, Carlsbad, CA, USA) at room temperature for $1 \mathrm{~h}$. Finally, the sections were counterstained with $1 \mathrm{mmol} / \mathrm{L}$ Hoechst 33258 (861405; Sigma) to label the nucleus. Images were captured using a confocal microscope (Fluoview1000; Olympus, Japan). In each set of experiments, images were taken with the same parameter settings.

\section{Isolation and culture of mesenteric artery endothelial cells}

Mesenteric artery endothelial cells (MACEs) from SS rats were isolated as previously described [17]. Briefly, SS rats that received heparin were anesthetized with $10 \%$ chloral hydrate $(4 \mathrm{~mL} / \mathrm{kg})$. The abdomen was open and the heart was perfused with sterile and chilled physiological saline solution (PSS) to remove circulating blood from blood vessels. PSS contained (in mM) $137 \mathrm{NaCl}, 5.4 \mathrm{KCl}, 0.05 \mathrm{CaCl}_{2}, 0.4 \mathrm{KH}_{2} \mathrm{PO}_{4}, 0.4$ $\mathrm{Na}_{2} \mathrm{HPO}_{4}, 4.4 \mathrm{NaHCO}_{3}$ and 10 HEPES ( $\mathrm{pH} 7.4$ with $\mathrm{HCl}$ ). The mesenteric vascular bed was dissected out and all of the vein branches of the mesenteric bed were rapidly excised under a dissecting microscope. The remaining arterial branches were digested with $0.2 \mathrm{mg} / \mathrm{mL}$ collagenase I for $1 \mathrm{~h}$ at $37^{\circ} \mathrm{C}$ with mild shaking. After centrifugation at $1000 \mathrm{rpm}$ for $5 \mathrm{~min}$, the pelleted cells were resuspended in Dulbecco's Modified Eagle Medium supplemented with 20\% FBS (v/v) and $50 \mu \mathrm{g} / \mathrm{mL}$ heparin, and were plated in gelatin-coated petri dish. After $2 \mathrm{~h}$, non-adherent cells were removed and adherent ECs were cultured at $37^{\circ} \mathrm{C}$ with $5 \% \mathrm{CO}_{2}$ for 3-5 days. The cells isolated from SS rats fed a HSD or NSD were used for the detection of TRPM4 protein expression. The initial batch of HUVECs were cultured in RPMI 1640 medium (Hyclone, South Logan, UT, USA) containing $10 \%$ fetal bovine serum (FBS) and supplemented with $1 \%$ penicillin and streptomycin. Cells were incubated at $37^{\circ} \mathrm{C}$ in an atmosphere of $95 \%$ air and $5 \% \mathrm{CO}_{2}$ in a humidified incubator.

\section{Culture and transfection of HUVECS}

HUVECs were grown until 70-80\% confluence, and were used in passages 4-6 for all of the subsequent experiments. Twenty-four hours after plating, cells were changed into serum-free medium for transfection. HUVECs were transfected with specific TRPM4 siRNA (GenePharma Co. Shanghai, China) or scrambled siRNA as negative control at a dose of $1 \mu \mathrm{g} / \mathrm{ml}$ for $24 \mathrm{~h}$ using LipofectamineTM 2000 (Invitrogen). The sequences of the TRPM4 siRNAs are shown in Table 1.

\section{Western blot analysis}

Tissue lysates ( $90 \mu \mathrm{g}$ per lane) from each experiment were analyzed by Western blotting. Briefly, HUVEC cultures were washed with ice-cold phosphate-buffered saline (PBS, and the mesenteric arteries were carefully isolated. Then the samples were extracted with the appropriate amount of lysis buffer, and homogenized with CelLytic M lysis reagent containing a protease inhibitor cocktail (Sigma, Poole,

Table 1. Sequence of the specific TRPM4 siRNAs used in our study. All of the siRNAs correspond to homo sapiens

\begin{tabular}{lll}
\hline Name & Sense $\left(5^{\prime}-3^{\prime}\right)$ & Antisense (5'-3') \\
\hline TRPM4 (siRNA1) & GACUGGAAUUGACAUCCCUTT & AGGGAUGUCAAUUCCAGUCTT \\
TRPM4 (siRNA2) & GAUCGAAUCAGGCGUUUCUTT & AGAAACGCCUGAUUCGAUCTT \\
TRPM4 (siRNA3) & GCUAGAGUUUGACAUGGAUTT & AUCCAUGUCAAACUCUAGCTT \\
Negative control & UUCUCCGAACGUGUCACGUTT & ACGUGACACGUUCGGAGAATT \\
\hline
\end{tabular}




\section{Cellular Physiology Cell Physiol Biochem 2017;41:835-848

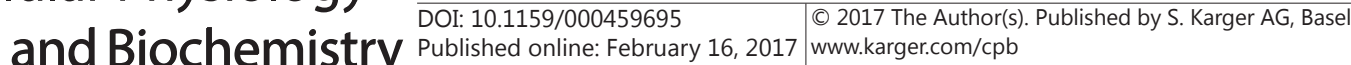 \\ Ding et al.: TRPM4 Involves in High Salt-Induced Endothelial Injury}

Dorset, UK). The proteins were resolved on 10\% SDS-PAGE gels, after which they were electrophoretically transferred to nitrocellulose membranes. After incubation in blocking solution (5\% nonfat milk; Sigma) for $1 \mathrm{~h}$ at room temperature, membranes were incubated overnight at $4^{\circ} \mathrm{C}$ with a $1: 200$ dilution of primary antibody against TRPM4 (ACC-044; Alomone, Jerusalem, Israel) and a 1:1000 dilution of primary antibody against $\beta$-actin (Zhongshan Jinqiao Biotechnology Co, Beijing, China). Thereafter, membranes were washed with PBS containing 0.05\% Tween-20 (PBS-T), followed by incubation for $1 \mathrm{~h}$ at room temperature with a 1:5000 dilution of secondary antibody (Odyssey, LICOR Corporate, Lincoln, NE, USA). Protein bands were visualized using the Li-COR Imaging System and were quantified with Odyssey CLx v2.1 software (LI-COR Biosciences) by measuring the band intensity (area $\times$ OD) in each group. TRPM4 protein expression was calculated using $\beta$-actin as the internal control.

\section{Cell viability}

Cell proliferation was measured using the 3-(4,5-dimehylthiazol-2-yl)-2,5-diphenyl tetrazolium bromide (MTT; Sigma) colorimetric assay. Briefly, HUVECs were cultured in 96-well plates at a density of $5 \times 10^{3}$ cells/well in $200 \mu \mathrm{l}$ culture medium. When cells reached about $80 \%$ confluency, they were challenged with different concentrations of $\mathrm{H}_{2} \mathrm{O}_{2}$ or aldosterone in serum-free medium. Then, $20 \mu \mathrm{L}$ PBSbuffered MTT ( $5 \mathrm{mg} / \mathrm{mL}$ ) solution was added to each well, and the cells were incubated at $37^{\circ} \mathrm{C}$ for $4 \mathrm{~h}$. Subsequently, the supernatant was discarded from each well and $100 \mu \mathrm{L}$ DMSO was added to each well and mixed thoroughly for $10 \mathrm{~min}$ to ensure that all of the crystals were dissolved. Vital cells were recorded by absorbance measurements at wavelength of $490 \mathrm{~nm}$ with monochromator microplate reader (Tecan, Mannedorf, Switzerland). The cell viability of HUVECs in each well was noted as a percentage of the control group. Six independent replicates were performed for each group.

The release of intracellular lactate dehydrogenase

Cytotoxicity was evaluated by determining the activity of lactate dehydrogenase (LDH) in culture media according to the manufacturer's instructions (LDH Cytotoxicity Assay Kit, C0017, Beyotime Biotechnology, Nantong, China) [18]. Briefly, cells were seeded in 96-well plates and were treated with different agents. Then the plates were centrifuged, after which the culture medium was collected. Next, a total of $120 \mu \mathrm{l}$ supernatant was transferred into a new 96-well plate, and then the LDH assay was initiated according to the protocol. LDH activity was measured at $490 \mathrm{~nm}$ with a microplate reader (Tecan, Mannedorf, Switzerland). Untreated cultures were presented as the control.

\section{TUNEL Assay}

In an effort to evaluate the degree of HUVEC apoptosis, we performed the terminal deoxynucleotidyl (TdT) transferase dUTP-biotin nick end-labeling (TUNEL) assay (1684795; Roche, Indianapolis, IN, USA) according to the manufacturer's recommendation and the cells were observed by fluorescence microscopy. For this experiment, cells were grown on glass coverslips and were treated with or without $200 \mathrm{nM} \mathrm{H}_{2} \mathrm{O}_{2}$ and $1 \mu \mathrm{M}$ 9-phenanthrol for $48 \mathrm{~h}$. Then, cells were fixed in freshly prepared 4\% paraformaldehyde for $1 \mathrm{~h}$ at room temperature. Next, the slides were carefully washed with PBS before they were immerged in 3\% $\mathrm{H}_{2} \mathrm{O}_{2}$ for $10 \mathrm{~min}$ at room temperature. Then the slides were permeabilized with $0.1 \%$ TritonX-100 (Sigma) for 2 min on ice, and washed with PBS twice. Then the cells were loaded with $50 \mu$ TUNEL reaction mixture in a humidified atmosphere for $1 \mathrm{~h}$ at $37^{\circ} \mathrm{C}$ in the dark. Following incubation, cells were gently washed with PBS and then counterstained with $1 \mathrm{mmol} / \mathrm{L}$ Hoechst 33258 (861405; Sigma) and rinsed twice with PBS. Images were captured at room temperature using a confocal microscope (Fluoview1000, Olympus) at emission wavelengths of $488 \mathrm{~nm}$ and $594 \mathrm{~nm}$. TUNEL-positive cells had green fluorescence and represented the apoptotic cells. TUNEL-stained cells were counted in five randomly selected fields per treatment group, and the number of Hoechst-positive cells (cells with blue fluorescence) was used to calculate the apoptotic index.

Flow cytometry analysis

Apoptosis of HUVECs was detected by flow cytometry using an annexin V-FITC Apoptosis Detection Kit I (BD Pharmingen, San Diego, CA, USA). In brief, HUVECs were grown to confluency and divided into six groups: (1) control group; (2) $\mathrm{H}_{2} \mathrm{O}_{2}(200 \mathrm{nM})$ group; (3) $\mathrm{H}_{2} \mathrm{O}_{2}(400 \mathrm{nM})$ group; (4) $\mathrm{H}_{2} \mathrm{O}_{2}(200 \mathrm{nM})$ +9-phenathrol group $(1 \mu \mathrm{M}) ;(5) \mathrm{H}_{2} \mathrm{O}_{2}(400 \mathrm{nM})+9$-phenathrol $(1 \mu \mathrm{M})$ group; and (6) 9-phenathrol $(1 \mu \mathrm{M})$ 


\section{Cellular Physiology Cell Physiol Biochem 2017;41:835-848

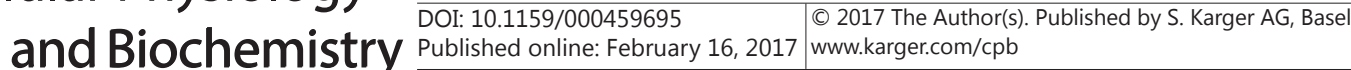

Ding et al.: TRPM4 Involves in High Salt-Induced Endothelial Injury

group. After treating, cells were stained with FITC-labeled annexin V and propidium iodide (PI) for 15 min in the dark at room temperature according to the manufacturer's protocol. Finally, the cells were analyzed using the FACS Calibur TM flow cytometry system (Becton Dickinson, San Jose, CA, USA).

\section{Migration assay}

HUVEC migration was performed using a 24-well Transwell chamber (Costar, Cambridge, MA, USA) with $8.0 \mu \mathrm{m}$ pore polycarbonate membrane inserts. A total of $\sim 1-1.5 \times 10^{5}$ cells HUVECs were suspended in $0.2 \mathrm{~mL}$ serum-free medium, seeded on the upper chamber, and allowed to adhere. Then cells were treated with or without $100 \mathrm{nM} \mathrm{H}_{2} \mathrm{O}_{2}, 1 \mu \mathrm{M}$ 9-phenanthrol, or both agents for $48 \mathrm{~h}$. Meanwhile, medium (500 $\left.\mu \mathrm{L}\right)$ with $10 \%$ FBS was added to the lower chamber to stimulate cell migration. Next, the cells were incubated at $37^{\circ} \mathrm{C}$ with $5 \% \mathrm{CO}_{2}$ for $24 \mathrm{~h}$ to allow migration. A cotton swab was used to remove non-invading cells on the upper surface of the membrane. The invading cells on the lower surface of the filter were fixed in $4 \%$ paraformaldehyde for $30 \mathrm{~min}$ at room temperature. After washing twice with PBS and air-drying, the invading cells were stained with $1 \%$ crystal violet for $15 \mathrm{~min}$ at room temperature. Five fields were photographed for each group using a Leica DM2700 M light microscope (Leica Microsystems GmbH, Wetzlar, Germany). Finally, the average number of migrated cells was evaluated by counting three random images per group, and the data are represented in terms of the fold change compared to the control values.

\section{Detection of cytokines in culture medium}

HUVECs were seeded in 96-well plates and subjected to four treatment conditions for $24 \mathrm{~h}$ : (1) serumfree medium as a control; (2) $200 \mu \mathrm{M} \mathrm{H}_{2} \mathrm{O}_{2}$; (3) $200 \mu \mathrm{M} \mathrm{H}_{2} \mathrm{O}_{2}$ + 9-Phenathrol (1 $\mu \mathrm{M}$ ); and (4) 9-Phenathrol (1 $\mu \mathrm{M})$. Cell culture supernatants were collected, after which concentrations of soluble intercellular adhesion molecule-1 (sICAM-1), soluble vascular cell adhesion molecule (sVCAM-1), and E-selectin were separately measured using enzyme-linked immunoassay (ELISA) kits according to the manufacturer's instructions. ELISA kits for sICAM-1 and sVCAM-1 were purchased from ExCell Biology, Inc (Shanghai, China), the ELISA kit for E-selectin was purchased from R\&D Systems (Minneapolis, MN, USA).

\section{Detection of intracellular reactive oxygen species production}

Confocal and immunofluorescence technology were used to examine reactive oxygen species (ROS) in the cells, as previously described [19]. Briefly, HUVECs were cultured on glass coverslips. After treatment with aldosterone in the presence or absence of 9-phenanthrol, tempol, eplerenone, or apocynin [20], the cells were washed twice with PBS and fixed in 4\% paraformaldehyde. Then cells were loaded with $2.5 \mu \mathrm{M}$ 5- (and-6)-carboxy-2',7'-dichlorodihydrofluorescein diacetate (carboxy-H2DCFDA), which is a membranepermeable ROS-sensitive fluorescent probe (Invitrogen) that becomes fluorescent when oxidized. Labeled cells were washed twice in PBS before confocal microscopy. ROS levels were measured by fluorescence intensity.

Data analysis

Data are presented as the mean \pm SD. Comparison between two groups was evaluated using the unpaired Student's $t$-test. Multiple group comparison was performed using 1-way analysis of variance (ANOVA). $P$ values less than 0.05 were considered statistically significant.

\section{Results}

TRPM4 expression is upregulated by a HSD in the vascular endothelium of SS rats

TRPM4 is involved in the regulation of the vascular endothelium in numerous pathological processes $[5,6]$. Thus, we presumed that it may be associated with endothelial lesions. Therefore, we examined whether TRPM4 expression might be altered during a HDS in the endothelium of Dahl/SS rats. Our results showed that TRPM4 was mainly expressed in the mesenteric artery vascular endothelial cells (MAVECs) and was localized near the plasma membrane (Fig. 1A). The expression levels appeared to be significantly increased in MAVECs 3 weeks after the HSD (Fig. 1A) in Dahl/SS rats, which was further confirmed by Western blotting analyses (Fig. 1B). Furthermore, TRPM4 was also expressed in HUVECs and 


\section{\begin{tabular}{ll} 
Cellular Physiology & Cell Physiol Biochem 2017;41:835-848 \\
\hline DOI: 10.1159/000459695 & 02017 The Author(s). Published by S. Karger AG, Basel
\end{tabular}

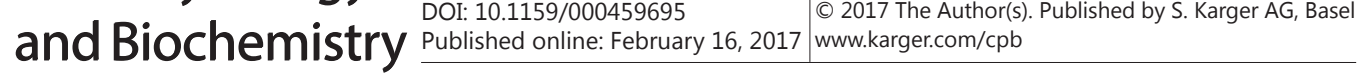 \\ Ding et al.: TRPM4 Involves in High Salt-Induced Endothelial Injury}

its expression levels were upregulated with the addition of $20 \mathrm{mM} \mathrm{NaCl}$ to the culture media (24 h) (Fig. 1C).

TRPM4 expression is increased upon application of $\mathrm{H}_{2} \mathrm{O}_{2}$ and aldosterone to vascular endothelial cells

Previous studies have suggested that a HSD causes oxidative stress [10-15] and increases the levels of circulating aldosterone [16] in Dahl/SS rats. Therefore we evaluated whether TRPM4 expression is upregulated upon application of exogenous $\mathrm{H}_{2} \mathrm{O}_{2}$ or aldosterone. To this end, HUVECs were first exposed to $200 \mu \mathrm{M} \mathrm{H}_{2} \mathrm{O}_{2}$ for $24 \mathrm{~h}$ and $48 \mathrm{~h}$, followed by Western blot analysis. The data show that the expression levels of TRPM4 were significantly enhanced by exogenous $\mathrm{H}_{2} \mathrm{O}_{2}$ (Fig. 2A). We treated HUVECS with 0, 50, 100, 200, and $400 \mu \mathrm{M} \mathrm{H}_{2} \mathrm{O}_{2}$ for 24 $\mathrm{h}$, and found that 200 and $400 \mu \mathrm{M} \mathrm{H}_{2} \mathrm{O}_{2}$ significantly upregulated the TRPM4 expression of TRPM4 (Fig. 2B). Then we examined the expression of TRPM4 in HUVECs after incubation with $200 \mathrm{nM}$ aldosterone for $24 \mathrm{~h}$ and $48 \mathrm{~h}$, and found that after incubation with $200 \mathrm{nM}$ aldosterone for $48 \mathrm{~h}$, TRPM4 expression was significantly upregulated, whereas treating cells with $200 \mathrm{nM}$ aldosterone for $24 \mathrm{~h}$ had no prominent effects on TRPM4 expression (Fig. 2C). Then we used $0,25,50,100$, and $200 \mathrm{nM}$ aldosterone to treat HUVECs for $48 \mathrm{~h}$, and found that the regulatory effects of aldosterone on TRPM4 expression were dose dependent, as shown in Fig. 2D. Since TRPM4 is a stress oxidative-sensitive ion channel, dithiothreitol (DTT) was used to test whether reducing environmental ROS inhibits TRPM4 expression [21]. Our results showed that the upregulated expression of TRPM4 caused by $\mathrm{H}_{2} \mathrm{O}_{2}$ was significantly prevented by pretreatment of $100 \mu \mathrm{M}$ DTT (Fig. 2E); however, the upregulated TRPM4 expression by aldosterone was not significantly affected by DTT pretreatment (data not shown). We also found that 9-phenanthrol (a specific TRPM4 blocker) not only inhibited TRPM4 activity, but also inhibited its protein expression. Our results also showed that 9-phenanthrol significantly inhibited the upregulation of TRPM4 caused by $\mathrm{H}_{2} \mathrm{O}_{2}$ (Fig. 2F).

Fig. 1. A high-salt diet led to an increase in TRPM4 expression in the endothelial cells. (A) Representative immunostaining images demonstrating the location and abundance of TRPM4 in the mesenteric artery endothelial cells of Dahl/SS rats fed a normal-salt $\operatorname{diet}$ (NSD) or high-salt diet (HSD) $(n=4)$. The white arrowhead indicates the location of TRPM4 expression on vascular endothelial cells. (B) The protein expression of TRPM4 in the mesenteric artery endothelium of Dahl/SS rat fed a NSD or HSD ( $n=6$ /group; $* P<0.05$ vs. normal salt group). (C) Representative Western blot following incubation of HUVECs with $\mathrm{HS}$ (20 $\mathrm{mM}$ additional $\mathrm{NaCl}$ in the medium) led to a significant increase in TRPM4 expression (n $=4$ /group; ${ }^{*} P<0.05$ vs. NS control group).

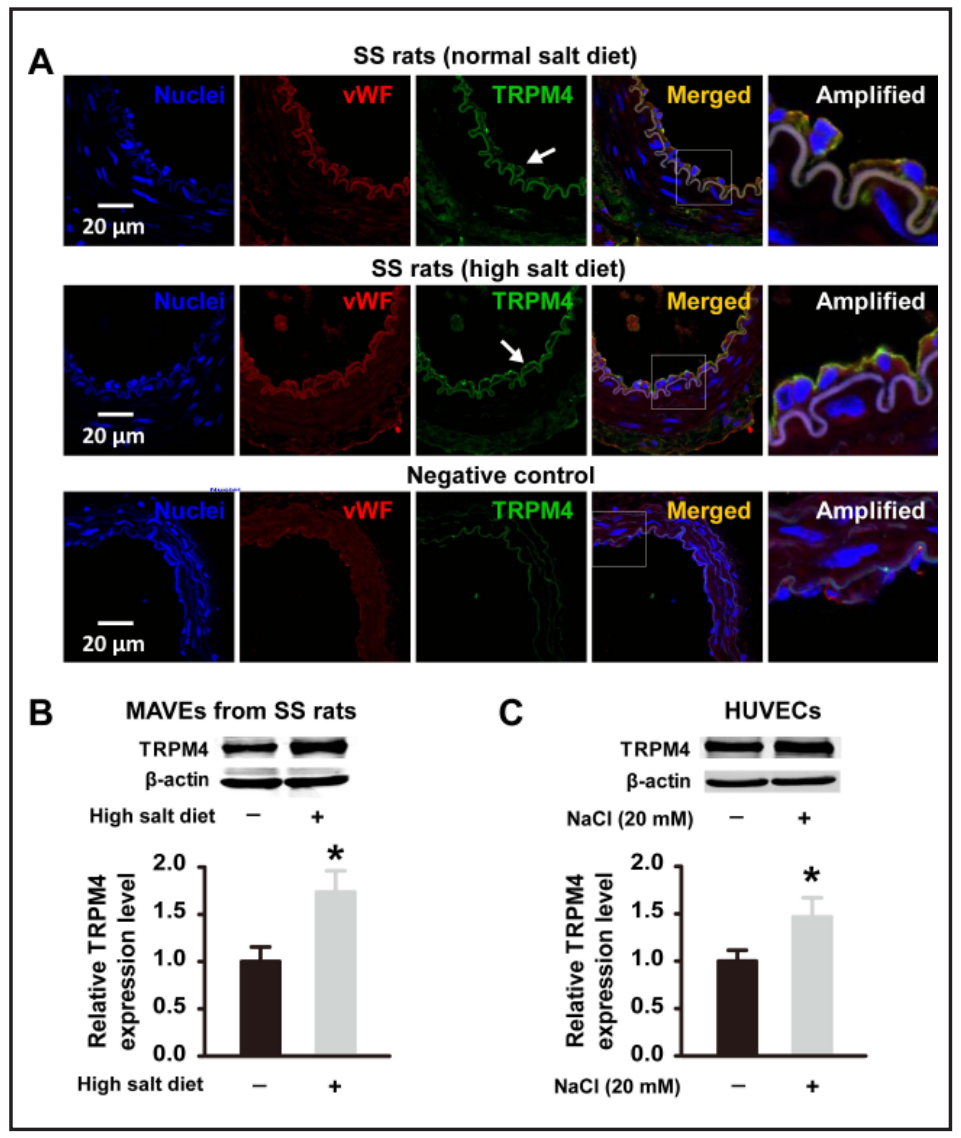

\section{KARGER}


Fig. 2. Exogenous application of $\mathrm{H}_{2} \mathrm{O}_{2}$ and aldosterone to HUVECs resulted in increased TRPM4 expression. (A) Representative Western blot showing TRPM4 expression in HUVECs treated with $200 \mu \mathrm{M} \mathrm{H}_{2} \mathrm{O}_{2}$ for $24 \mathrm{~h}$ or 48 h. (B) $\mathrm{H}_{2} \mathrm{O}_{2}$ upregulated the protein expression of TRPM4 in a dose-dependent manner in HUVECs. (C) Representative Western blots showing TRPM4 expression in HUVECs treated with $200 \mathrm{nM}$ aldosterone for 24 h or 48 h. (D) Aldosterone upregulated the protein expression of TRPM4 in a dose-dependent manner in HUVECs. (E) Reduction of environmental ROS generated by DTT inhibited the upregulation of TRPM4 expression caused by $\mathrm{H}_{2} \mathrm{O}_{2}$. (F) 9-phenanthrol, a specific TRPM4 inhibitor, significantly inhibited the upregulation of TRPM4 expression caused by $\mathrm{H}_{2} \mathrm{O}_{2}(\mathrm{n}=4) ;{ }^{*} P<$ 0.05 vs. $0 \mathrm{nM}$; ${ }^{\#} P<0.05$ vs. $\mathrm{H}_{2} \mathrm{O}_{2}$ or aldosterone treatment. Ctrl: control; Ald: aldosterone.

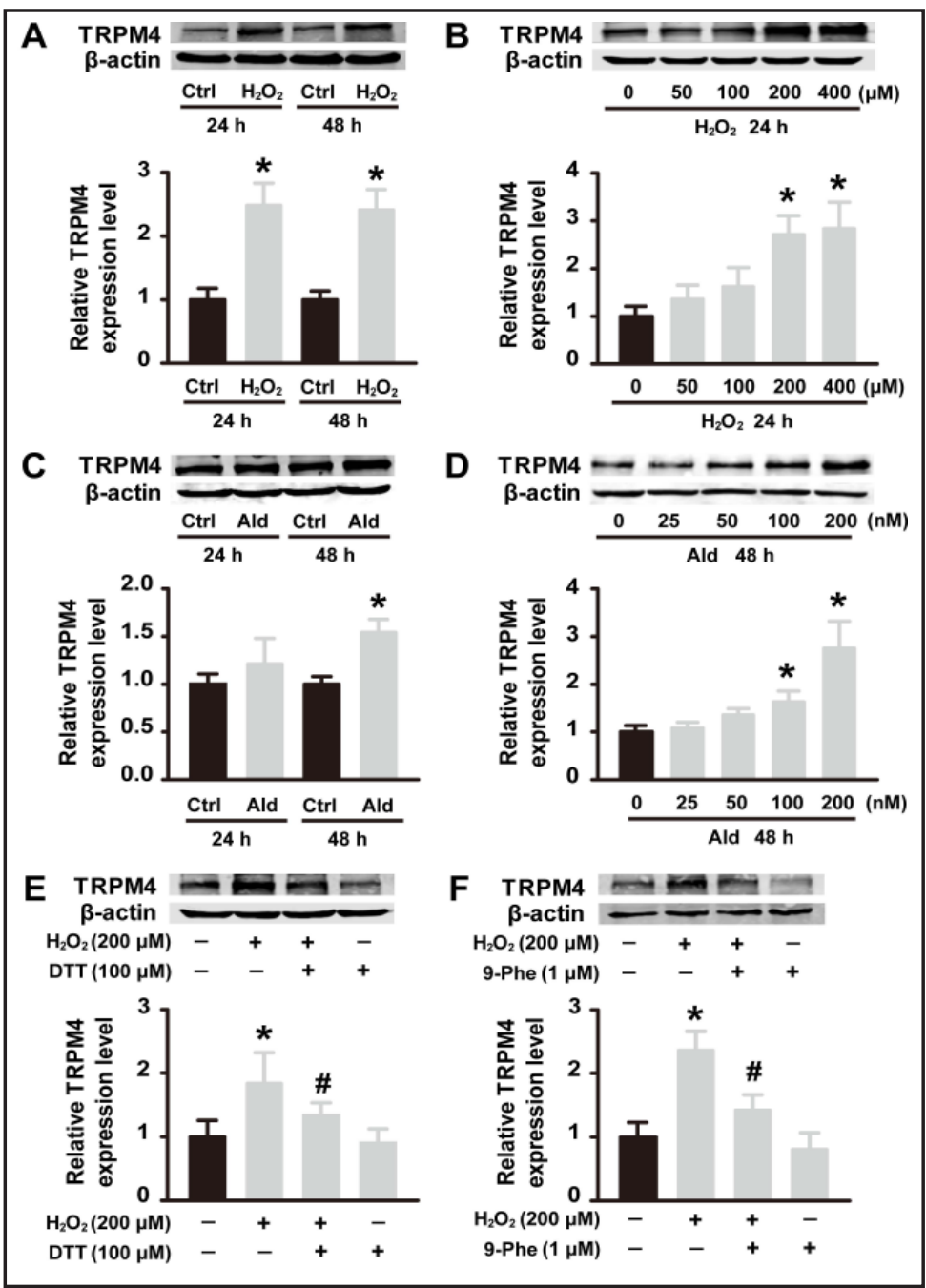

Together, these results suggest that TRPM4 may play a potential role in early endothelial damage caused by oxidative stress and increased aldosterone levels.

Inhibition of TRPM4 attenuates $\mathrm{H}_{2} \mathrm{O}_{2}$ - and aldosterone-induced decreases in cell viability and increases in cell death

To evaluate the contribution of TRPM4 to EC viability, HUVECs were pretreated with several concentrations of $\mathrm{H}_{2} \mathrm{O}_{2}(0,25,50,100,200,400 \mu \mathrm{M})$ or aldosterone $(0,12.5,25,50$, $100,200 \mathrm{nM}$ ) in the absence or presence of 9 -phenanthrol, followed by cell viability assays. The results showed that cell viability was decreased by $\mathrm{H}_{2} \mathrm{O}_{2}$ in a concentration-dependent manner (Fig. 3A, B). Interestingly, in cells pretreated with $1 \mu \mathrm{M}$ 9-phenanthrol, the $200 \mu \mathrm{M}$ $\mathrm{H}_{2} \mathrm{O}_{2}$-induced reduction of cell viability was significantly rescued (Fig. 3A, B). Moreover, treatment of cells with $50-200 \mathrm{nM}$ aldosterone for $48 \mathrm{~h}$ also led to a dose-dependent decrease in cell viability; similarly, the decreased cell viability caused by $200 \mathrm{nM}$ aldosterone was partly reversed by $1 \mu \mathrm{M}$ 9-phenanthrol (Fig. 3C). Treatment of cells with 25-400 $\mu \mathrm{M}$ $\mathrm{H}_{2} \mathrm{O}_{2}$ culture for $24 \mathrm{~h}$ or $48 \mathrm{~h}$ increased LDH release into HUVECs, and $1 \mu \mathrm{M}$ 9-phenanthrol significantly prevented the cell death caused by $200 \mu \mathrm{M} \mathrm{H}_{2} \mathrm{O}_{2}$ (Fig. 3D, E). Aldosterone at concentrations of 50-200 nM also promoted cell death, and 9-phenanthrol significantly inhibited the cell death caused by $200 \mathrm{nM}$ aldosterone (Fig. 3F). However, treatment with 9-phenanthrol at concentrations up to $2 \mu \mathrm{M}$ had no effects on cell viability or cell death (data not shown). Then we used specific TRPM4 siRNA to knock down TRPM4 expression in HUVECs. The knockdown efficiency of TRPM4 expression is shown in Fig. 3G. The decreased 


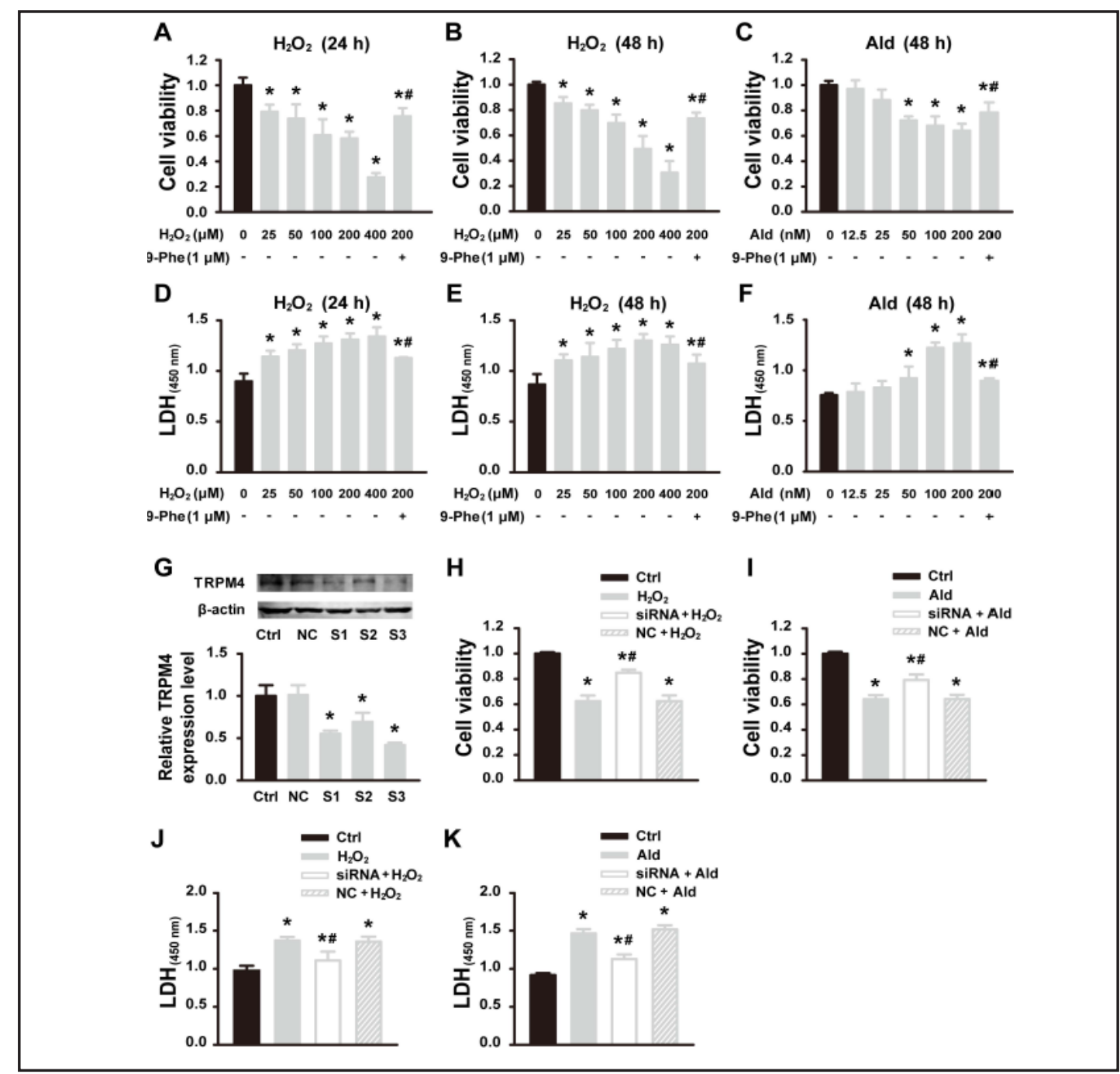

Fig. 3. TRPM4 contributes to $\mathrm{H}_{2} \mathrm{O}_{2}$ - and aldosterone-induced decreases in cell viability and increases in cell death. HUVECs were pretreated with $1 \mu \mathrm{M}$ 9-phenanthrol for $1 \mathrm{~h}$, followed by treatment with different concentrations of $\mathrm{H}_{2} \mathrm{O}_{2}$ or aldosterone for the indicated time points. The MTT assay showed that incubation of HUVECs with $\mathrm{H}_{2} \mathrm{O}_{2}$ for $24 \mathrm{~h} \mathrm{(A)} \mathrm{and} 48 \mathrm{~h}$ (B), and aldosterone for $48 \mathrm{~h}$ (C) decreased cell viability, in a concentration-dependent manner; 9-phenanthrol partially reversed $\mathrm{H}_{2} \mathrm{O}_{2}$ and aldosterone-induced inhibition of cell viability ( $\mathrm{n}=5$ independent experiments for each condition). Measurements of LDH release showed that incubation of HUVECs with $\mathrm{H}_{2} \mathrm{O}_{2}$ for $24 \mathrm{~h}$ (D) and $48 \mathrm{~h}(\mathrm{E})$, and aldosterone for $48 \mathrm{~h} \mathrm{(F)} \mathrm{enhanced} \mathrm{cell}$ death in a concentration-dependent manner; 9-phenanthrol partially reversed $\mathrm{H}_{2} \mathrm{O}_{2}$ and aldosterone-induced cell death ( $\mathrm{n}=5$ independent experiments for each condition). (G) Representative Western blot of HUVECs transfected with specific TRPM4 siRNA reduced TRPM4 protein expression by 60\%. Knockdown of TRPM4 prevented $\mathrm{H}_{2} \mathrm{O}_{2}-(\mathrm{H})$ and aldosterone-mediated (I) damage to cell viability, and inhibited $\mathrm{H}_{2} \mathrm{O}_{2}-(\mathrm{J})$ and aldosterone-mediated $(\mathrm{K})$ cell death in HUVECs ( $\mathrm{n}=4$ independent experiments for each condition). ${ }^{*} P$ $<0.05$ vs. control; ${ }^{\#} P<0.05$ compared to $\mathrm{H}_{2} \mathrm{O}_{2}$ - or aldosterone-treated cells. Ctrl: control; 9-Phe: 9-phenanthrol; Ald: aldosterone.

cell viability caused by $200 \mu \mathrm{M} \mathrm{H}_{2} \mathrm{O}_{2}$ or $200 \mathrm{nM}$ aldosterone was significantly reversed by TRPM4 siRNA, but was not affected by a scrambled negative control sequence (Fig. $3 \mathrm{H}, \mathrm{I}$ ). Similarly, the enhanced cell death by $\mathrm{H}_{2} \mathrm{O}_{2}$ or aldosterone was also prevented by TRPM4 knockdown (Fig. 3J, K). Together, these results suggest that TRPM4 may play a role in $\mathrm{H}_{2} \mathrm{O}_{2}$ and aldosterone-induced endothelium injury. 
A

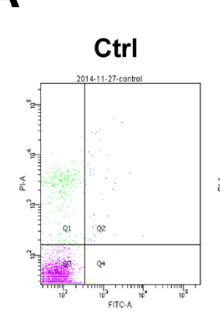

$200 \mu \mathrm{M} \mathrm{H}_{2} \mathrm{O}_{2}$
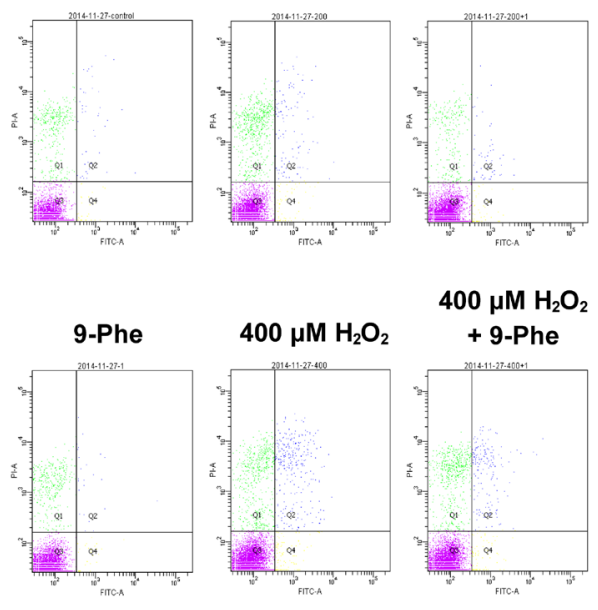

C

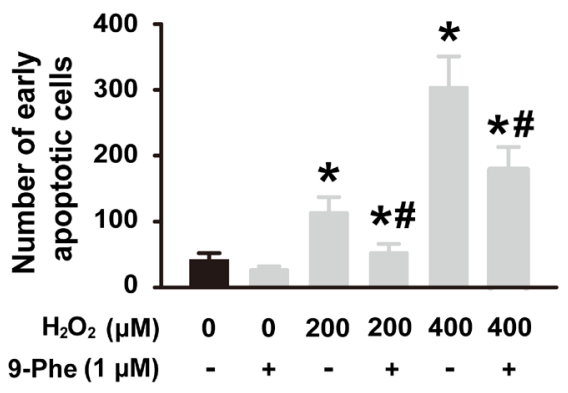

B

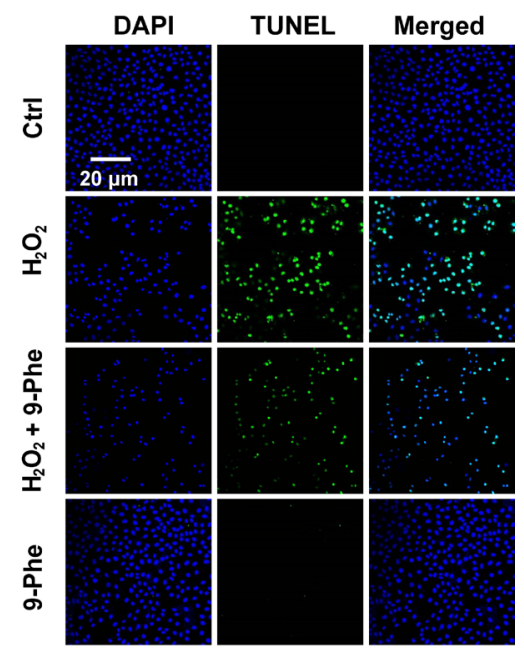

D

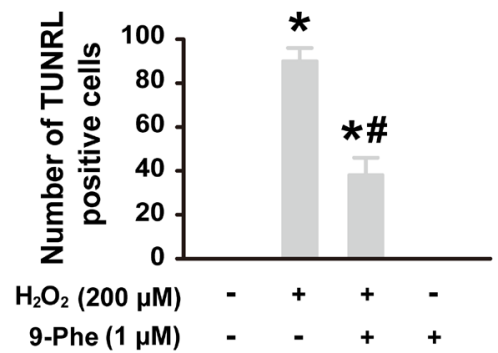

Fig. 4. $\mathrm{H}_{2} \mathrm{O}_{2}$-induced apoptosis of HUVECs was inhibited by 9-phenanthrol. (A) Representative results obtained from Annexin V-propidium iodide (PI) two-color flow cytometry assays under the indicated experimental conditions. (B) Statistical analysis showing the number of apoptotic cells, as measured by Annexin V-PI flow cytometry and shown in (A) ( $n=4$ independent experiments for each indicated condition). (C) Representative images of TUNEL staining showed that the $\mathrm{H}_{2} \mathrm{O}_{2}$-induced apoptosis of HUVECs was partially inhibited by 9-phenanthrol. (D) Statistical analysis of TUNEL staining as shown in (C) ( $\mathrm{n}=4$ independent experiments for each indicated condition; ${ }^{*} P<0.05$ vs. control, ${ }^{*} P<0.05$ vs. $\mathrm{H}_{2} \mathrm{O}_{2}$-treated cells). Ctrl: control; 9-Phe: 9-phenanthrol.

TRPM4 is involved in $\mathrm{H}_{2} \mathrm{O}_{2}$-mediated apoptosis of HUVECS

To gain further insight into the involvement of TRPM4 in cell apoptosis, two-color flow cytometry was performed using Annexin V and PI. HUVECs were treated with $200 \mu \mathrm{M}$ or $400 \mu \mathrm{M} \mathrm{H}_{2} \mathrm{O}_{2}$ for $24 \mathrm{~h}$, in the absence or presence of $1 \mu \mathrm{M}$ 9-phenanthrol. As shown in Fig. $4 \mathrm{~A}$ and $4 \mathrm{~B}$, the number of apoptotic HUVECs was significantly increased by $200 \mu \mathrm{M} \mathrm{H}_{2} \mathrm{O}_{2}$; as the concentration increased to $400 \mu \mathrm{M}$ the number of apoptotic HUVECs increased. Furthermore, $\mathrm{H}_{2} \mathrm{O}_{2}$-induced apoptosis was greatly attenuated by 9-phenanthrol (Fig. 4A, B). Accordingly, TUNEL staining assays confirmed that 9-phenanthrol could significantly reduce the number of $\mathrm{H}_{2} \mathrm{O}_{2}$-induced apoptotic HUVECs (Fig. 4C, D). These results suggest that inhibition of TRPM4 could prevent oxidative stress-induced apoptosis of ECs.

TRPM4 regulates cell migration and cytokine release in HUVECS

To further investigate the role of TRPM4 in the early-stage damage of vascular endothelial cells, cell migration and cytokines related to cell adhesion were evaluated. First, we used the transwell assay to determine whether $\mathrm{H}_{2} \mathrm{O}_{2}$ leads to an increase in cell migration and whether 9-phenanthrol inhibits $\mathrm{H}_{2} \mathrm{O}_{2}$-induced cell migration. The data show that the 


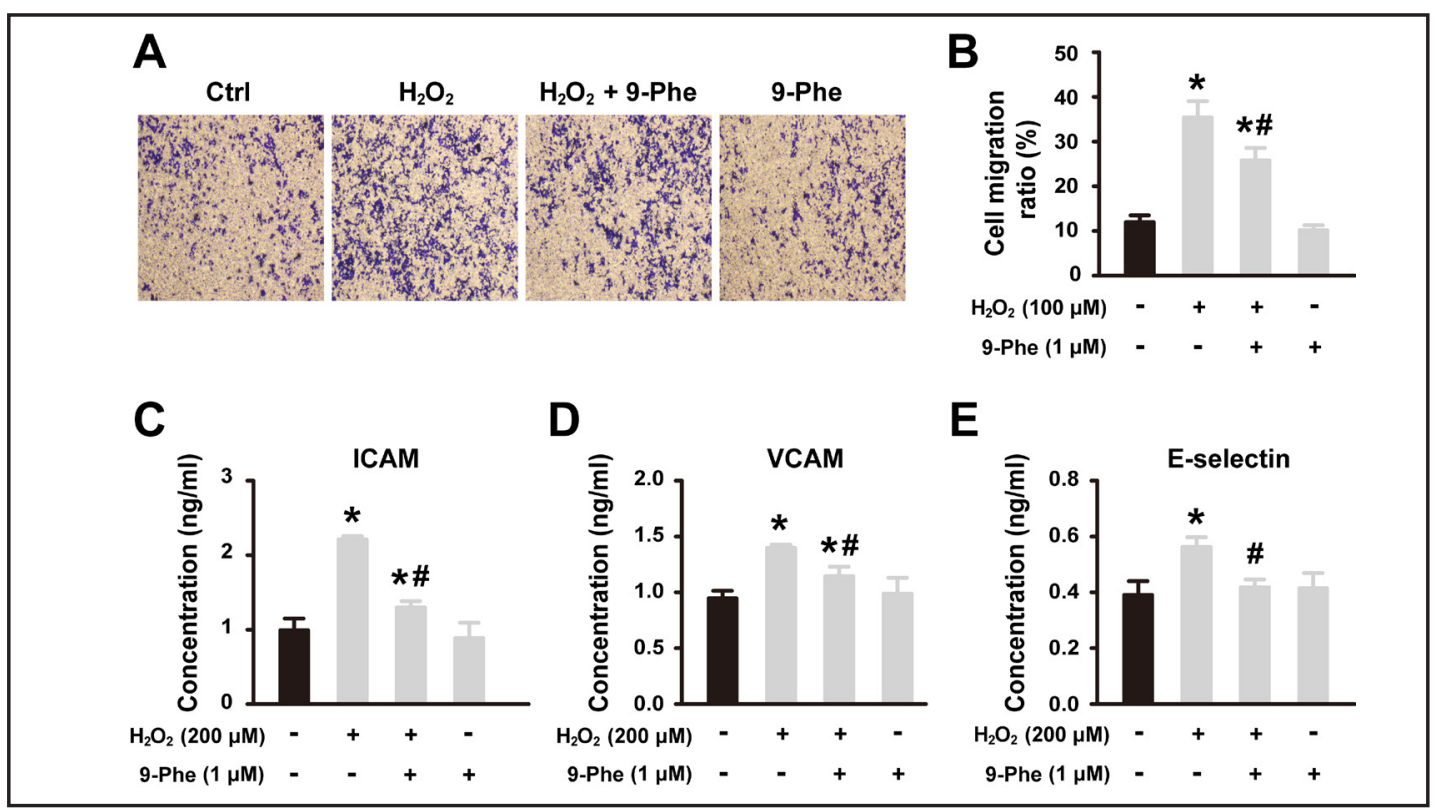

Fig. 5. 9-phenanthrol attenuates the stimulatory effects of $\mathrm{H}_{2} \mathrm{O}_{2}$ on migration and adhesion of HUVECs. (A) Representative images of the transwell assays performed under the indicated conditions. The HUVECs were treated with $100 \mu \mathrm{M} \mathrm{H}_{2} \mathrm{O}_{2}$ for $48 \mathrm{~h}$ in the presence or absence of 9-phenanthrol. (B) Statistical analysis demonstrating that $\mathrm{H}_{2} \mathrm{O}_{2}$-mediated migration was significantly inhibited by 9-phenanthrol. (C-E) The HUVECs were treated with $200 \mu \mathrm{M} \mathrm{H}_{2} \mathrm{O}_{2}$ for $24 \mathrm{~h}$ in the presence or absence of 9-phenanthrol. Relative concentrations of adhesion molecules were measured by ELISA assays under the indicated experimental conditions; $\mathrm{H}_{2} \mathrm{O}_{2}$-induced significant increases in the levels of ICAM-1 (C), VCAM-1 (D), and E-selectin (E) were greatly attenuated by 9-phenanthrol ( $\mathrm{n}=4$ independent experiments); ${ }^{*} P<0.05$ vs. control, ${ }^{\#} P<0.05$ vs. $\mathrm{H}_{2} \mathrm{O}_{2}$-treated cells. Ctrl: control; 9-Phe: 9-phenanthrol.

numbers of migrated cells were significantly increased by $200 \mu \mathrm{M} \mathrm{H}_{2} \mathrm{O}_{2}$, which were greatly inhibited by 9-phenanthrol (Fig. 5A, B). To further characterize the role of TRPM4 in cell adhesion, ELISA kits were used to examine ICAM-1, VCAM-1, and E-selectin secretion levels in HUVECs under different experimental conditions. After incubation of HUVECs with 200 $\mu \mathrm{M} \mathrm{H}_{2} \mathrm{O}_{2}$ for $24 \mathrm{~h}$, a significant increase in the release of soluble ICAM-1 (Fig. 5C), VCAM-1 (Fig. 5D), and E-selectin (Fig. 5E) into the media was observed. As expected, inhibition of TRPM4 by 9-phenanthrol significantly reduced $\mathrm{H}_{2} \mathrm{O}_{2}$-mediated adhesion molecule release. These results demonstrate that inhibition of TRPM4 significantly reduced oxidative stressmediated increase in the migration rate of HUVECs, as well as the release of adhesion molecules into these cells.

\section{TRPM4 contributes to aldosterone-mediated oxidative stress in HUVECs}

The fluorescent intensity of carboxy-H2DCFDA (a membrane-permeable ROS-sensitive probe) was used as an index of intracellular ROS levels. The ROS levels were significantly increased upon application of $200 \mu \mathrm{M} \mathrm{H}_{2} \mathrm{O}_{2}$ for $24 \mathrm{~h}$; these effects were abolished by DTT, tempol (a free radical scavenger), and apocynin (a specific NADPH oxidase inhibitor) [22], and were significantly attenuated by 9-phenanthrol (Fig. 6A, B). Accordingly, incubation of cells with $200 \mathrm{nM}$ aldosterone for $48 \mathrm{~h}$ led to a significant increase in intracellular ROS levels, which was significantly attenuated by 9 -phenanthrol. Interestingly, aldosterone-induced increases in intracellular ROS were dramatically inhibited by DTT, temple, apocynin, and eplerenone (a selective aldosterone blocker) (Fig. 6C, D). These results suggest that TPRM4 contributes to aldosterone-mediated oxidative stress. 


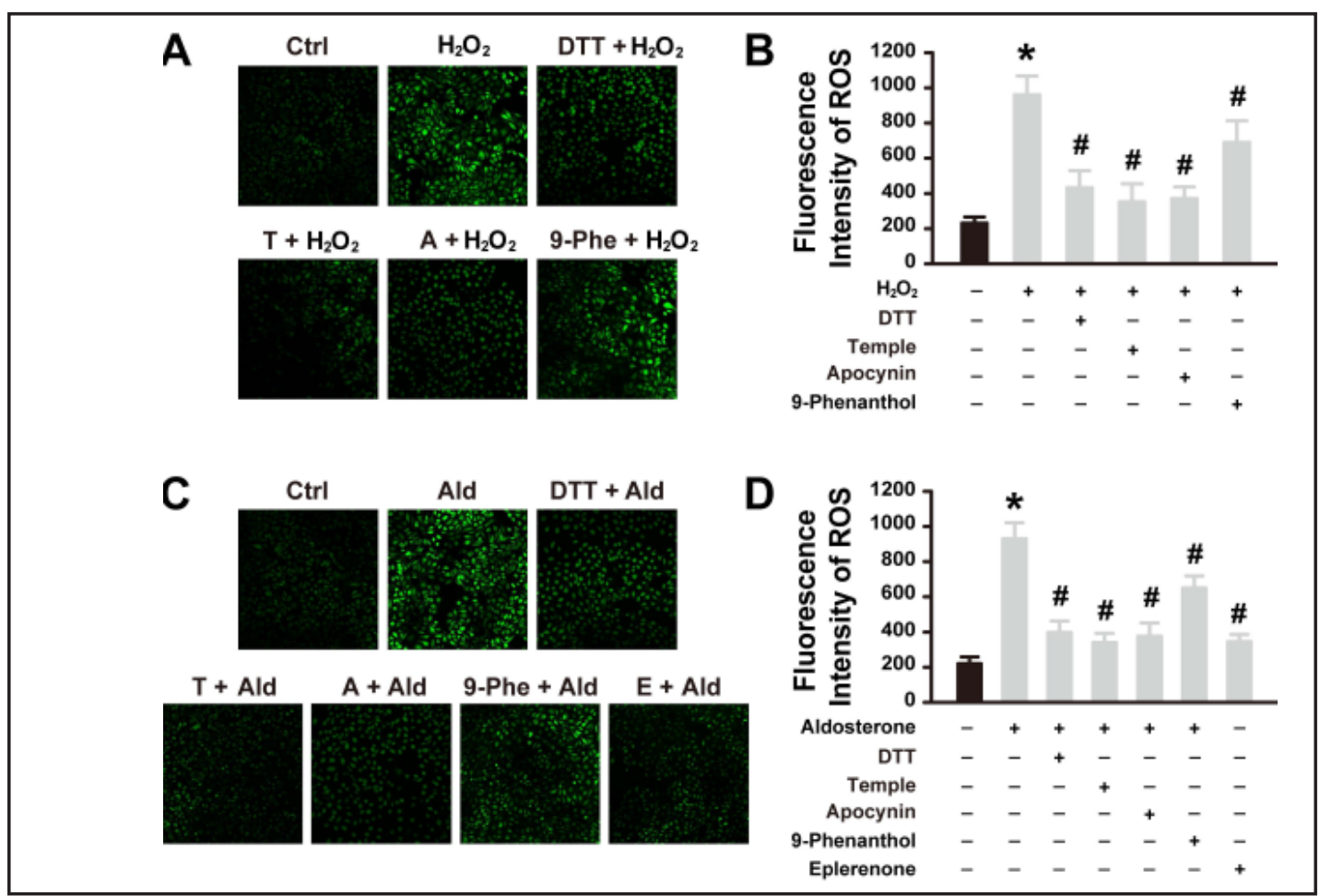

Fig. 6. Aldosterone- or $\mathrm{H}_{2} \mathrm{O}_{2}$-mediated accumulation of intracellular ROS was greatly inhibited by 9-phenanthrol. HUVECs were incubated with $200 \mathrm{MM} \mathrm{H}_{2} \mathrm{O}_{2}$ for $24 \mathrm{~h}$ or $200 \mathrm{nM}$ aldosterone for $48 \mathrm{~h}$ in the absence or presence of $100 \mu \mathrm{M}$ DTT, $250 \mu \mathrm{M}$ tempol, $200 \mu \mathrm{M}$ apocynin, $10 \mu \mathrm{M}$ eplerenone, or $1 \mu \mathrm{M}$ 9-phenanthrol (A) Representative confocal images showing intracellular ROS levels in HUVECs under the indicated conditions. (B) Relative fluorescence intensities indicating intracellular ROS levels analyzed from experiments shown in (A) $(n=3)$. (C) Representative confocal images demonstrating intracellular ROS levels in HUVECs under the indicated conditions. (D) Relative fluorescence intensities indicating intracellular ROS levels analyzed from experiments shown in (C) $(\mathrm{n}=3)$. ${ }^{*} P<0.05$ vs. control, ${ }^{\#} P<0.05$ vs. aldosterone or $\mathrm{H}_{2} \mathrm{O}_{2}$-treated cells. Ctrl: control; T: tempol; A: apocynin; 9-Phe: 9-phenanthrol; Ald: aldosterone.

\section{Discussion}

In this study, we presented evidence that a HSD leads to a significant increase in TRPM4 expression in the vascular endothelium of Dahl/SS rats and in cultured HUVECs. Our results demonstrated that exposure of ECs to aldosterone resulted in oxidative stress and eventually induced apoptosis and increases in cell migration and adhesion, possibly due to the increased expression of TRPM4. Therefore, TRPM4 may be a potential therapeutic target for the prevention and treatment of endothelium disorders.

The Dahl/SS rat is a genetic model of SS hypertension, and exhibits many phenotypic characteristics in common with human hypertensive patients. A HSD leads to hypertension in SS rats, resulting in oxidative stress [10-15] and an increase in plasma aldosterone concentrations [16] compared to Dahl/SS rats fed a NSD. In recent years, it has been demonstrated that excessive accumulation of ROS induces oxidative stress, which in turn contributes to the initiation and development of diverse diseases [23, 24] such as atherosclerosis, hypertension, diabetic vascular complications, and heart failure [25]. Consistent with the results of previous studies, we found that 3 weeks after being on a HSD, the blood pressure and circulating aldosterone levels dramatically increased in these Dahl/SS rats compared to those fed a NSD (unpublished observations). We examined the expression levels of TRPM4 in the mesenteric artery endothelium of Dahl/SS rats fed either HSD or NSD as well as HUVECs treated with HS. Both a HSD in Dahl/SS rats and HS to treat 
HUVECs significantly increased the expression levels of TRPM4, suggesting that TRPM4 may be an important element in the pathophysiological processes of SS hypertension.

Oxidative stress and vascular dysfunction occur in Dahl/SS rats fed an HSD [13-15]. A study by Coombes et al. [26] showed the participation of oxidative stress in regulating the expression of TRPM7 in endothelial cells. ROS are intracellular chemically reactive chemical species containing oxygen and include superoxide $\left(\mathrm{O}_{2}^{-}\right), \mathrm{H}_{2} \mathrm{O}_{2}$ [27], and the hydroxyl radical $\left(\mathrm{OH}^{-}\right)$, among which $\mathrm{H}_{2} \mathrm{O}_{2}$ is one of the common and stable forms. Thus, we used $\mathrm{H}_{2} \mathrm{O}_{2}$ to treat HUVECs in order to mimic oxidative stress-induced endothelium damage. Exposure to $\mathrm{H}_{2} \mathrm{O}_{2}$ led to significant cell death, which was partially reversed by the specific TRPM4 blocker, 9-phenanthrol. Furthermore, the secretion of several major adhesion molecules, including ICAM-1, VCAM-1, and E-selectin, was dramatically increased by the application of $\mathrm{H}_{2} \mathrm{O}_{2}$ to HUVECs. However, the regulatory effects of $\mathrm{H}_{2} \mathrm{O}_{2}$ on adhesion molecules were greatly attenuated by 9-phenanthrol. Several studies have shown that other adhesion molecules, such as VE-cadherin and PECAM-1 (CD31), can be modulated by TRPM4 [28] and TRPM7 [29]. Endothelial dysfunction is a complex and multistep process that includes endothelial cell migration [30-33]. Our data clearly demonstrate that $\mathrm{H}_{2} \mathrm{O}_{2}$ considerably promotes EC migration and that inhibition of TRPM4 with 9-phenanthrol significantly inhibits $\mathrm{H}_{2} \mathrm{O}_{2}$ induced migration of HUVECs. These results are consistent with those from the study by Sarmiento et al. [21], which showed that EC migration is dependent on TRPM4 [21]. In addition, TRPM7 also modulates EC migration caused by oxidative stress [34, 35]. These in vitro results are consistent with the notion that TRPM4 is an important contributor to oxidative stress-induced endothelium dysfunction.

As an integral component of the renin-angiotensin-aldosterone system, aldosterone plays an essential role in the modulation of intracellular ion exchange activity to control electrolyte balance, fluid homeostasis, and blood pressure [36]. Aldosterone mainly acts on the principal cells of the renal collecting duct, although it also acts on extra renal targets including the cardiovascular system $[37,38]$. In addition, mounting evidence has revealed that aldosterone causes endothelial dysfunction, but the underlying mechanism remains unclear [39]. Aldosterone is a permissive factor for the effects of minor increases in plasma sodium concentration on EC dysfunction [40]. In addition to reducing blood pressure in HSDinduced hypertensive Dahl/SS rats, eplerenone (a selective aldosterone blocker) reverses the effects on renal and vascular damage [41]. Oxidative stress and increased circulating aldosterone levels co-exist in Dahl/SS rats with salt-induced hypertension [10-16], and studies have shown that aldosterone can induce oxidative stress [42-44]. For example, after intracerebraventricular infusion of aldosterone for 14 days, the rats had increased blood pressure and heart rate, enhanced oxidative stress, and endothelial dysfunction [44]. Our in vitro results showed that aldosterone increased the intracellular ROS levels in HUVECs. Most importantly, the enhanced oxidative stress caused by aldosterone or $\mathrm{H}_{2} \mathrm{O}_{2}$ was mediated by TRPM4.

Taken together, the data in this study suggest that TRPM4 plays an important role in HSD-induced endothelium damage, which is associated, at least in part, with HS or aldosterone-mediated oxidative stress. Our results shed light on how TRPM4 contributes to early-stage endothelial damage in hypertensive models induced by a HSD.

\section{Acknowledgments}

This work was supported by the Key Project of Chinese National Program for Fundamental Research and Development (973 Program 2014CB542401, 2012CB517803 to ZZ), the National Natural Science Foundation of China (81270340 and 81320108002 to ZZ, 31400983 to TB, and 81570240 to DZ), and the Heilongjiang Province Outstanding Youth Foundation (JC201315 to WC). 


\section{Cellular Physiology Cell Physiol Biochem 2017;41:835-848

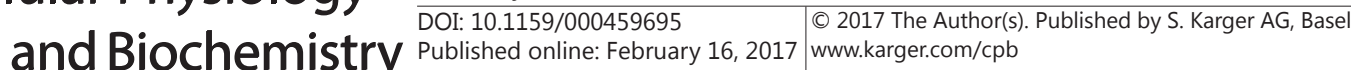 \\ Ding et al.: TRPM4 Involves in High Salt-Induced Endothelial Injury}

\section{Disclosure Statement}

None.

\section{References}

1 Simard JM, Woo SK, Gerzanich V: Transient receptor potential melastatin 4 and cell death. Pflugers Arch 2012;464:573-582.

-2 Abriel H, Syam N, Sottas V, Amarouch MY, Rougier JS: Trpm4 channels in the cardiovascular system: Physiology, pathophysiology, and pharmacology. Biochem Pharmacol 2012;84:873-881.

-3 Becerra A, Echeverria C, Varela D, Sarmiento D, Armisen R, Nunez-Villena F, Montecinos M, Simon F: Transient receptor potential melastatin 4 inhibition prevents lipopolysaccharide-induced endothelial cell death. Cardiovasc Res 2011;91:677-684.

4 Gerzanich V, Woo SK, Vennekens R, Tsymbalyuk O, Ivanova S, Ivanov A, Geng Z, Chen Z, Nilius B, Flockerzi V, Freichel M, Simard JM: De novo expression of trpm4 initiates secondary hemorrhage in spinal cord injury. Nat Med 2009;15:185-191.

5 Earley S, Brayden JE: Transient receptor potential channels and vascular function. Clin Sci 2010;119:19-36.

-6 Vennekens R, Nilius B: Insights into trpm4 function, regulation and physiological role. Handb Exp Pharmacol 2007:269-285.

7 Simard C, Hof T, Keddache Z, Launay P, Guinamard R: The trpm4 non-selective cation channel contributes to the mammalian atrial action potential. J Mol Cell Cardiol 2013;59:11-19.

8 Guinamard R, Hof T, Del Negro CA: The trpm4 channel inhibitor 9-phenanthrol. Br J Pharmacol 2014;171:1600-1613.

9 Mathar I, Jacobs G, Kecskes M, Menigoz A, Philippaert K, Vennekens R: Trpm4. Handb Exp Pharmacol 2014;222:461-487.

10 Mori T, O'Connor PM, Abe M, Cowley AW, Jr.: Enhanced superoxide production in renal outer medulla of dahl salt-sensitive rats reduces nitric oxide tubular-vascular cross-talk. Hypertension 2007;49:1336-1341.

11 Zhang J, Chen S, Liu H, Zhang B, Zhao Y, Ma K, Zhao D, Wang Q Ma H, Zhang Z: Hydrogen sulfide prevents hydrogen peroxide-induced activation of epithelial sodium channel through a pten/pi(3,4,5)p3 dependent pathway. PLoS One 2013;8:e64304.

12 Fujita M, Fujita T: The role of cns in the effects of salt on blood pressure. Curr Hypertens Rep 2016;18:10.

13 de Cavanagh EM, Ferder LF, Ferder MD, Stella IY, Toblli JE, Inserra F: Vascular structure and oxidative stress in salt-loaded spontaneously hypertensive rats: Effects of losartan and atenolol. Am J Hypertens 2010;23:1318-1325.

14 Papazzo A, Conlan X, Lexis L, Lewandowski P: The effect of short-term canola oil ingestion on oxidative stress in the vasculature of stroke-prone spontaneously hypertensive rats. Lipids Health Dis 2011;10:180.

15 Zalba G, San Jose G, Moreno MU, Fortuno MA, Fortuno A, Beaumont FJ, Diez J: Oxidative stress in arterial hypertension: Role of nad(p)h oxidase. Hypertension 2001;38:1395-1399.

16 Morizane S, Mitani F, Ozawa K, Ito K, Matsuhashi T, Katsumata Y, Ito H, Yan X, Shinmura K, Nishiyama A, Honma S, Suzuki T, Funder JW, Fukuda K, Sano M: Biphasic time course of the changes in aldosterone biosynthesis under high-salt conditions in dahl salt-sensitive rats. Arterioscler Thromb Vasc Biol 2012;32:1194-1203.

17 Liu HB, Zhang J, Sun YY, Li XY, Jiang S, Liu MY, Shi J, Song BL, Zhao D, Ma HP, Zhang ZR: Dietary salt regulates epithelial sodium channels in rat endothelial cells: Adaptation of vasculature to salt. Br J Pharmacol 2015;172:5634-5646.

18 Sun B, Cai Y, Li Y, Li J, Liu K, Li Y, Yang Y: The nonstructural protein np1 of human bocavirus 1 induces cell cycle arrest and apoptosis in hela cells. Virology 2013;440:75-83.

19 Wang Q, Song B, Jiang S, Liang C, Chen X, Shi J, Li X, Sun Y, Wu M, Zhao D, Zhang ZR, Ma HP: Hydrogen sulfide prevents advanced glycation end-products induced activation of the epithelial sodium channel. Oxid Med Cell Longev 2015;2015:976848.

20 Kim SJ, Wong PK: ROS upregulation during the early phase of retroviral infection plays an important role in viral establishment in the host cell. J Gen Virol 2013;94:2309-2317.

21 Sarmiento D, Montorfano I, Cerda O, Caceres M, Becerra A, Cabello-Verrugio C, Elorza AA, Riedel C, Tapia P, Velasquez LA, Varela D, Simon F: Increases in reactive oxygen species enhance vascular endothelial cell migration through a mechanism dependent on the transient receptor potential melastatin 4 ion channel. Microvasc Res 2015;98:187-196. 


\section{Cellular Physiology Cell Physiol Biochem 2017;41:835-848 and Biochemistry Published on/00459695 16, $2017 \begin{aligned} & \text { (C) } 2017 \text { The Author(s). Published by S. Karger AG, Basel } \\ & \text { www.karger.com/cpb }\end{aligned}$}

Ding et al.: TRPM4 Involves in High Salt-Induced Endothelial Injury

-22 El-Sawalhi MM, Ahmed LA: Exploring the protective role of apocynin, a specific nadph oxidase inhibitor, in cisplatin-induced cardiotoxicity in rats. Chem Biol Interact 2014;207:58-66.

23 Closa D, Folch-Puy E: Oxygen free radicals and the systemic inflammatory response. IUBMB life 2004;56:185-191.

-24 Cross CE, Halliwell B, Borish ET, Pryor WA, Ames BN, Saul RL, McCord JM, Harman D: Oxygen radicals and human disease. Ann Intern Med 1987;107:526-545.

25 Bryan N, Ahswin H, Smart N, Bayon Y, Wohlert S, Hunt JA: Reactive oxygen species (ros)--a family of fate deciding molecules pivotal in constructive inflammation and wound healing. Eur Cell Mater 2012;24:249265.

26 Coombes E, Jiang J, Chu XP, Inoue K, Seeds J, Branigan D, Simon RP, Xiong ZG: Pathophysiologically relevant levels of hydrogen peroxide induce glutamate-independent neurodegeneration that involves activation of transient receptor potential melastatin 7 channels. Antioxid Redox Signal 2011;14:1815-1827.

27 Winterbourn CC: The biological chemistry of hydrogen peroxide. Methods Enzymol 2013;528:3-25.

28 Echeverria C, Montorfano I, Cabello-Verrugio C, Armisen R, Varela D, Simon F: Suppression of transient receptor potential melastatin 4 expression promotes conversion of endothelial cells into fibroblasts via transforming growth factor/activin receptor-like kinase 5 pathway. J Hypertens 2015;33:981-992.

-29 Echeverria C, Montorfano I, Hermosilla T, Armisen R, Velasquez LA, Cabello-Verrugio C, Varela D, Simon F: Endotoxin induces fibrosis in vascular endothelial cells through a mechanism dependent on transient receptor protein melastatin 7 activity. PLoS One 2014;9:e94146.

-30 Chen X, Cai J, Zhou X, Chen L, Gong Y, Gao Z, Zhang H, Huang W, Zhou H: Protective effect of spironolactone on endothelial-to-mesenchymal transition in huvecs via notch pathway. Cell Physiol Biochem 2015;36:191200.

-31 Cui Y, Xie X, Jia F, He J, Li Z, Fu M, Hao H, Liu Y, Liu JZ, Cowan PJ, Zhu H, Sun Q, Liu Z: Ambient fine particulate matter induces apoptosis of endothelial progenitor cells through reactive oxygen species formation. Cell Physiol Biochem 2015;35:353-363.

-32 Li J, Li J, Wei T, Li J: Down-regulation of microrna-137 improves high glucose-induced oxidative stress injury in human umbilical vein endothelial cells by up-regulation of ampkalpha1. Cell Physiol Biochem 2016;39:847-859.

-33 Zhong ZY, Tang Y: Upregulation of periostin prevents high glucose-induced mitochondrial apoptosis in human umbilical vein endothelial cells via activation of nrf2/ho-1 signaling. Cell Physiol Biochem 2016;39:71-80.

34 Baldoli E, Castiglioni S, Maier JA: Regulation and function of trpm7 in human endothelial cells: Trpm7 as a potential novel regulator of endothelial function. PLoS One 2013;8:e59891.

35 Sarmiento D, Montorfano I, Caceres M, Echeverria C, Fernandez R, Cabello-Verrugio C, Cerda O, Tapia P, Simon F: Endotoxin-induced vascular endothelial cell migration is dependent on tlr4/nf-kappab pathway, $\operatorname{nad}(p) h$ oxidase activation, and transient receptor potential melastatin 7 calcium channel activity. Int J Biochem Cell Biol 2014;55:11-23.

36 Schiffrin EL: Effects of aldosterone on the vasculature. Hypertension 2006;47:312-318.

-37 Fritsch Neves M, Schiffrin EL: Aldosterone: A risk factor for vascular disease. Curr Hypertens Rep 2003;5:59-65.

-38 Glasser SP, Selwyn AP, Ganz P: Atherosclerosis: Risk factors and the vascular endothelium. Am Heart J 1996;131:379-384.

-39 Nguyen Dinh Cat A, Jaisser F: Extrarenal effects of aldosterone. Curr Opin Nephrol Hypertens 2012;21:147156.

40 Ritz E, Koleganova N: Aldosterone in uremia - beyond blood pressure. Blood Purif 2010;29:111-113.

-41 Eatman D, Layas MF, Bayorh MA: Eplerenone suppresses salt-induced vascular endothelial growth factor expression in the kidney. Kidney Blood Press Res 2010;33:167-173.

42 Briet M, Barhoumi T, Mian MO, Coelho SC, Ouerd S, Rautureau Y, Coffman TM, Paradis P, Schiffrin EL: Aldosterone-induced vascular remodeling and endothelial dysfunction require functional angiotensin type 1a receptors. Hypertension 2016;67:897-905.

-43 Dinh QN, Young MJ, Evans MA, Drummond GR, Sobey CG, Chrissobolis S: Aldosterone-induced oxidative stress and inflammation in the brain are mediated by the endothelial cell mineralocorticoid receptor. Brain Res 2016;1637:146-153.

44 Huang BS, Zheng H, Tan J, Patel KP, Leenen FH: Regulation of hypothalamic renin-angiotensin system and oxidative stress by aldosterone. Exp Physiol 2011;96:1028-1038. 